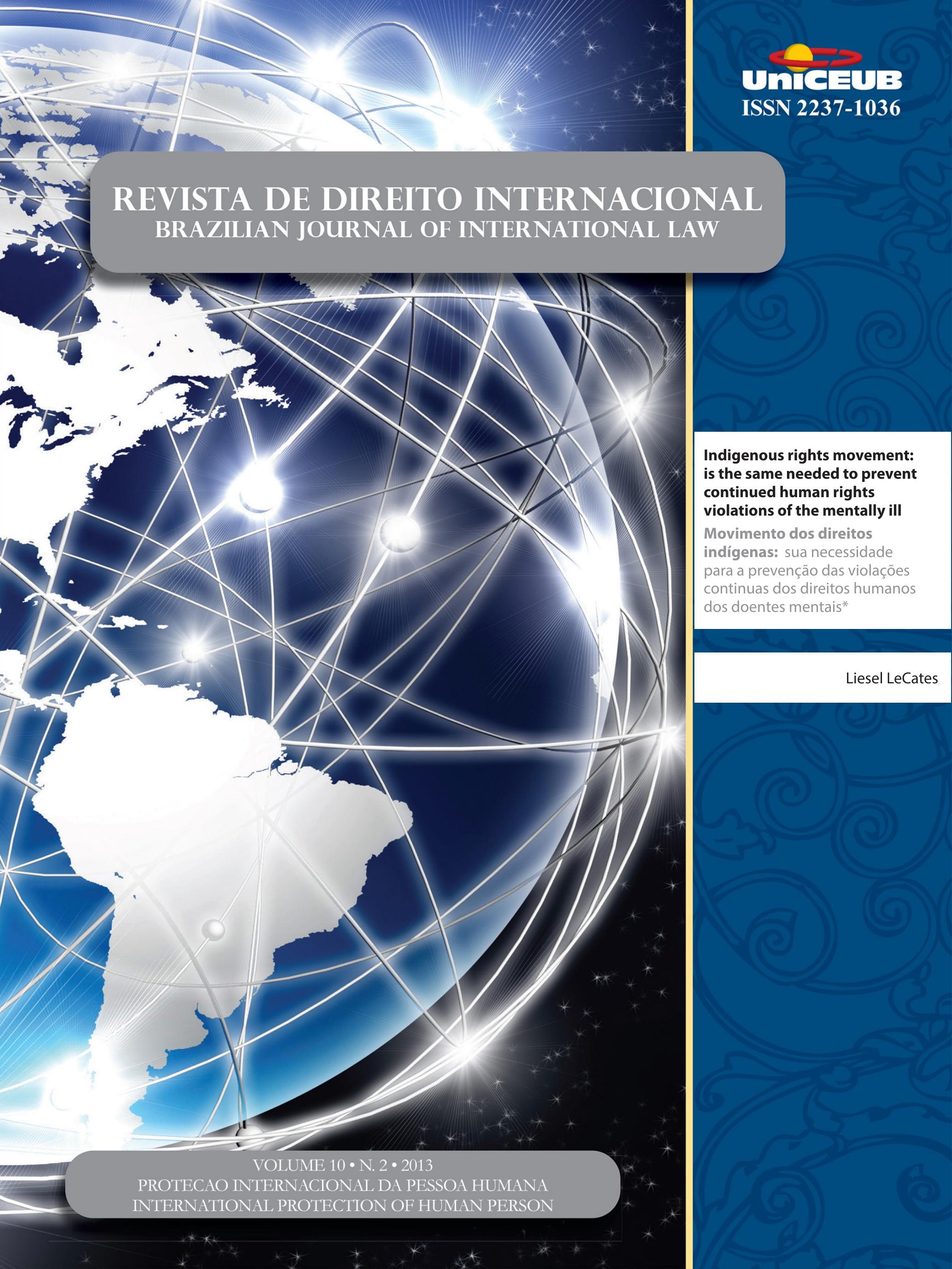




\section{Artigo Especial}

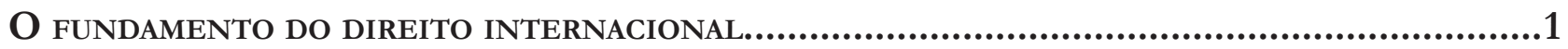
Alfred Verdross

\section{Proteção Internacional dos Direitos Humanos}

INDIGENOUS RIGHTS MOVEMENT: IS THE SAME NEEDED TO PREVENT CONTINUED HUMAN RIGHTS VIOLATIONS OF THE MENTALLY ILL

Liesel LeCates

O Discurso DAS DROGAS CONSTRUído PELO DIREITO INTERNACIONAL

Camila Soares Lippi

O ESTADO DEMOCRÁTICO DE DIREITO LAICO E A "NEUTRALIDADE" ANTE A INTOLERÂNCIA RELIGIOSA

Antonio Baptista Gonçalves

UM DiREITO SEM ESTADO? DiREITOS humanos E A FORMAÇÃo DE UM NOVO QUADRo NORMATIVO GLOBAL .87

Anderson Vichinkeski Teixeira e Rafael Köche

\section{Direito Humanitário}

The U.N. Standard Minimum Rules for the Treatment of Prisoners and North Korea: How North Korea is Violating these Rules with its Operation of the Yodok Concentration CAMP.

Tom Theodore Papain

U.S. Institutionalized Torture with Impunity: Examining Rape and Sexual Abuse in Custody Through the ICTY JurisprudenCE. 126 Allison Rogne 
Abduction, Torture, Interrogation: An Argument Against Extraordinary RendiTION

Kaitlyn E. Tucker

United States and European Union approaches to the death penalty: America SHOULD CONSIDER A NEW PERSPECTIVE 155 Katie R Hill

Tudo DE NOVO NO FRONT: MONUSCO, UMA NOVA ERA NAS PEACEKEEPING OPERATIONS? .169 Priscila Fett

A ADMINISTRAÇÃo DE TERRITÓRIOS OCUPADOS: INDETERMINAÇÃO DAS NORMAS DE DIREITO INTERNACIONAL HUMANITÁRIO?. 184 João Henrique Ribeiro Roriz, Fabia Fernandes Carvalho Veçoso e Lucas da Silva Tasquetto

THE (IN)APPLICABILITY OF THE STATUTE OF REFUGEES TO ENVIRONMENTALLY DISPLACED PERSONS 197 Maria Cláudia da Silva Antunes de Souza e Lucas de Melo Prado

\section{Sistema Interamericano de Direitos Humanos}

A contribuição da Comissão Interamericana de Direitos Humanos para o acesso À jus-

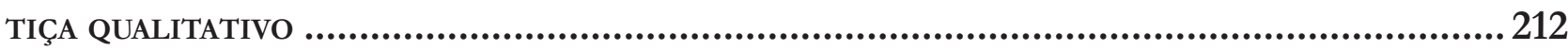
Márcio Antônio de Oliveira Filho, Ana Caroline Portes de Oliveira, Jéssica Galvão Chaves e Warlen Soares Teodoro

A executividade das sentenças da Corte Interamericana de Direitos Humanos no

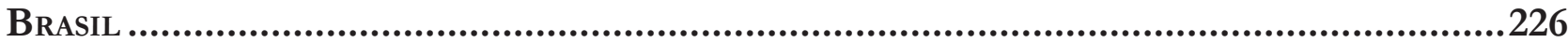

Augusto César Leite de Resende

A efetividade do ativismo jurídico transnacional no Sistema Interamericano de DiREITOS HuMANOS: UMA ANÁLISE A PARTIR DE CASOS CONTRA O BRASIL .................................238 Renata Mantovani de Lima e Lucélia de Sena Alves

O Processo e o Direito Coletivo no Sistema Interamericano de Direitos Humanos: UMA ANÁLISE COM BASE NA JURISPRUDÊNCIA INTERNACIONAL ...........................................250 Laercio Dias Franco Neto e Dafne Fernandez de Bastos 
CORTE INTERAMERICANA DE DIREITOS HUMANOS: OPINIÃo CONSULTIVA 4/84 - A MARGEM DE

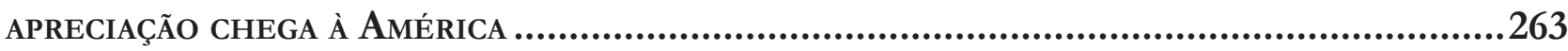

Paloma Morais Corrêa

A "PLENA" LIBERDADE DE EXPRESSÃo E OS DIREITOS HUMANOS: ANÁLISE DA JURISPRUDÊNCIA DA Corte InTeramericana de Direitos Humanos e o Julgamento da ADPF 130 281 Natália Paes Leme Machado

A proteção do meio ambiente no Sistema Interamericano de Direitos Humanos a parTIR DO DIREITO À EDUCAÇÃO.

Augusto César Leite de Resende

Parameters and procedures of the Inter-American System of Human Rights in CHILDREN'S RIGHTS VIOLATION LAWSUITS

Maria Guiomar da Cunha Frota e Pedro Alves Barbosa Neto

Poverty as a Violation of Human Rights: THE CASE OF STREET CHILDREN IN GUATEMALA AND BRAZIL

Paloma Morais Correa

\section{Proteção Internacional dos Direitos Humanos e o Direito Brasileiro}

A LEI N. 11.340/06 E SUAS REPERCuSSõES No CONTRATO INDIVIDUAL DE TRABALHo. Humberto Lima de Lucena Filho e Waldeny Pereira Filho

ORIENTAÇÃo SEXUAL E DISCRIMINAÇão NO AMBIENTE LABORAL

Glaucia Fernanda Oliveira Martins Batalha

NORMAS EDITORIAIS 


\title{
Indigenous rights movement: is the same needed to prevent continued human rights violations of the mentally ill
}

\author{
Movimento dos direitos indígenas: sua \\ necessidade para a prevenção das violações \\ continuas dos direitos humanos dos doentes \\ mentais*
}

Liesel LeCates**

\section{Abstract}

Known as "society's lepers," the mentally ill endure suffering that transcends borders. This affliction is often the result of cross-cultural social stigma, and includes treatments such as chaining people to beds and solitary confinement. Some scholars have proposed the necessity of an international convention to further obligate states to protect the interest of the mentally ill, but this action alone is insufficient. In order to decrease stigma, and the injustice inflicted upon the mentally ill, the root of social stigma must be degraded prior to the successful implementation of mental health legislation. Changes in societal perspectives and an increase in mental health awareness will positively impact, not only those suffering from mental illness, but society as a whole. But, how should this be done? Unlike past scholarship, this article addresses current problems associated with mental health treatment, and through an interdisciplinary approach, compares the effects of the indigenous rights movement to a mental health movement. Specifically, this article discusses the potential to effectuate change through an analysis of current problems which include: (1) lack of available care, (2) lack of cooperation to acquire the multidisciplinary action necessary to care for the mentally ill, (3) lack of Education, and (4) lack of effective mental health policy. Through integrating social movement theory, the article bridges the gap between laws and effective implementation, which has the potential to curb continued human rights violations of the mentally ill.

Keyword: Global, Mental Health, Indigenous Rights, Social Movement, International law

* Recebido em 03/10/2013

Aprovado em 14/10/2013

** University of California, Berkeley. Email: liesel.lecates@law.utah.edu

\section{Resumo}

Conhecidos como "leprosos da sociedade" os doentes mentais vivem o sofrimento que transcende fronteiras. Esta aflição é muitas vezes o resultado do estigma social transcultural, e inclui tratamentos como amarrar as pessoas à camas e submetê-las a confinamento solitário. Alguns acadêmicos têm proposto a necessidade de uma convenção internacional para obrigar os Esta- 
dos a proteger o interesse dos doentes mentais, mas esta ação por si é insuficiente. A fim de diminuir o estigma e a injustiça infligidos aos doentes mentais, a raiz deste estigma social deve ser combatida antes da implementação bem-sucedida da legislação de saúde mental. Mudanças nas perspectivas sociais e um aumento na consciência da saúde mental terá um impacto positivo sobre, não somente aqueles que sofrem de doença mental, mas também para a sociedade como um todo. Mas, como isso deve ser feito? Ao contrário de estudos passados, o presente artigo aborda problemas atuais associados com o tratamento de saúde mental, e através de uma abordagem interdisciplinar, compara os efeitos do movimento dos direitos indígenas a um movimento de saúde mental. Especificamente, este artigo discute o potencial para efetuar a mudança através de uma análise dos problemas atuais, que incluem: (1) a falta de assistência disponível, (2) a falta de cooperação para adquirir a ação multidisciplinar necessário para cuidar dos doentes mentais, (3) a falta da educação, e (4) a falta de política de saúde mental eficaz. Através da teoria da integração dos movimentos sociais, o artigo faz a ponte entre as leis e a implementação efetiva que tem o potencial para reduzir as violações continuas dos direitos humanos dos doentes mentais.

Palavras chaves: Global, saúde mental, direitos dos povos indígenas, movimento social, direito internacional.

\section{INTRODUCTION}

The World Health Organization ("WHO") has recognized the plight of those suffering from mental illness as a "hidden emergency" that needs to be addressed immediately. Known as "society's lepers," the mentally ill suffer horrific circumstances that exaggerate mental illnesses. ${ }^{3}$ Treatment commonly includes solitary confinement and chaining people to beds. ${ }^{4}$

When addressing many human rights violations, the moral wrongfulness of a violation is universally recog-

1 WHO Quality Rights Project - addressing a bidden emergency, World Health Organization (2013), available at http://www.who.int/mental_health/policy/quality_rights/en/.

2 D. L. Rosenhan, Symposium, On Being Sane in Insane Places, 13 Santa ClaraLawyer 379, 390 (1973), available at http:/ digitalcommons.law.scu.edu/lawreview/vol13/iss3/3

3 WHO Quality Rights Project - addressing a hidden emergency (2013).

4 Id. nized. Genocide, torture, withholding food and water; all of these wrongs evoke a cross-cultural feeling of injustice. Thus, these abuses can be approached in similar ways; through treaties that further obligate states to uphold human rights standards followed by domestic legislation and international pressure. However, mental illnesses should to be approached differently from many human rights violations because the injustice is not necessarily promoted by the state, but communities and families. Due to cross-cultural stigma, obliging states to abide by rules regarding the human rights of those suffering from mental ailments is necessary; yet, insufficient alone. To effectively change current treatment practices associated with the mentally ill, social changes must occur to penetrate cultural practice and to inform individual persons of the misconceptions and stigmas associated with these disabilities and illnesses.

The United States and other developed nations have long-imposed cultural ideas of proper human treatment on developing states. However, developed nations have historically failed to recognize basic human rights of the mentally ill and disabled. Although the poor are disproportionately affected, the stigma associated with mental illness is a global problem, one which penetrates cultures and political lines. Due to the scope of the violations, further degradation of cultural stigmas must be increased cross culturally and nationally before adequate legislation can be passed and effectuated.

In order to change societal perceptions, a social movement must take place resulting in increased public awareness and political activism. That said, there is difficulty in assessing a balance between the necessary restrictions on freedom through the institutionalization of the dangerous or severely ill; however, the current balance is often weighed down by the over-breadth of patients institutionalized. Therefore, this article does not promote the elimination of mandatory institutionalization for those who are a danger to self or others, but rather promotes legislation to protect persons from unnecessary involuntary commitment, and inhumane and degrading treatment while institutionalized.

Financing is an additional problem, many global struggles could be corrected with adequate financing; however, the global financing is insufficient to provide community care, and adequate treatment for every person suffering from mental illness. To solve the problems through increased financing would be an unreasonable expectation when 
the international community has failed to provide even the basic necessities of life such as food and shelter. Therefore, this paper illustrates social mechanisms necessary to improve international treatment of the mentally ill through a change is stigma rather than idealistic, costly care or institutionalization. The theoretical product of changed views includes an increase in financing; but this paper proposes that instead of merely attempting change through traditional international human rights treaties, or increased financing, there exist a need for a collaborative social approach. The topic will be subdivided, discussing the need for a mental health social movement through seven sections. First, the meaning of mental health and illnesses will be discussed. Second, the stigmatized problems associated with the current mental health system will be summarized in four sections: (1) lack of available care, (2) lack of cooperation to acquire the multidisciplinary action necessary to care for the mentally ill, (3) lack of Education, and (4) lack of effective mental health policy. Third, particular problems will be identified in the context of both developed and developing countries using specific examples of the United States, Great Britain, and Ghana. Fourth, mental illnesses will be distinguished from other groups suffering human rights violations. Fifth, the applicable principles of social movement theory will be briefly addressed. Sixth, a synopsis of the indigenous rights movement. Lastly, the previous sections will be applied to the mental health crisis in order to stipulate the effects of a global mental health movement.

Specifically, through the seven sections, the paper will attempt to demonstrate that in order to reduce cultural stigma and discrimination, the international community should continue to promote and recognize mistreatment of individuals through social movements. These social movements could effectuate change not only in international and domestic legislation, but also increase awareness of illness while changing society's views of the mentally ill.

\section{What is Mental Health and lllness?}

First, to know how to adequately treat a disease or ailment, the condition must be differentiated from health. Yet there exists difficulty in separating the mentally fit from mentally ill. The World Health Organization has described mental health as:

Not just the absence of mental disorder. It is defined as a state of well-being in which every individual realizes his or her own potential, can cope with the normal stresses of life, can work productively and fruitfully, and is able to make a contribution to her or his community. ${ }^{5}$

The Princeton Web Definition of mental illness includes "any disease of the mind; the psychological state of someone who has emotional or behavioral problems serious enough to require psychiatric intervention." Although a generally accepted definition, difficulties in distinguishing mental infirmities manifest through psychosomatic complaints should also be considered. Often society fails to recognize that there is not a bright line between mental health and physical health. From a holistic approach, the two are bound and one condition can lead to the other. However, current definitions cause difficulty in distinguishing a psychosomatic physical complaint from a primary physical ailment, further leading to complexity when diagnosing the mentally ill. Mental illness is a grand scheme which, although affected by environmental factors such as poverty; strikes all races, cultures, and people of all socioeconomic status. ${ }^{7}$ The failure to identify and treat these illnesses in a timely and appropriate manner can lead to significant long-term costs as failure to treat is associated with criminal behavior, homelessness, and unemployment. ${ }^{8}$

\section{Why the Current Mental Health System IS FAILING?}

\subsection{Stigma of Mental Illness}

The ability to treat mental illness is compounded by the societal stigma associated. Stigma is described as "a mark separating individuals from one another based on a socially conferred judgment that some persons or

5 What is Mental Health, World Health Organization (Sept 3 2007), available at http://www.who.int/features/qa/62/en/index.html.

6 Mental Illness, WordNet Search 3.1, available at http://wordnetweb.princeton.edu/perl/webwn?s $=$ mental $\% 20$ illness (last visited April 6, 2013).

7 Mental Illnesses, National Alliance on Mental Illness (2006-2013) available at http://www.nami.org/template.cfm?section=about_ mental_illness (last visited April 6, 2013).

8 See generally Draine, Jeffrey, et al., Role of social disadvantage in crime, joblessness, and homelessness among persons with serious mental illness, Psychiatric Services 53.5, 565-573 (2002), available at http:/ /journals.psychiatryonline.org $/$ article.aspx? Volume $=53 \&$ page $=565 \&$ journalID $=18$ 
groups are tainted and "less than."'9 A World Health Organization Bulletin cites Gruskin and Ferguson, from Harvard's Program on International Health and Human Rights, who state that "stigma" is the state of "being devalued by individuals or communities on the basis of real or perceived health status." ${ }^{\prime 10}$ Stigma is often intertwined with discrimination which as defined by the authors: "refers to the legal, institutional and procedural ways that people are denied access to their rights because of their real or perceived health status." ${ }^{11}$ Further, "Recent research continues to show that individuals fear and avoid persons with mental illness, even as psychiatry claims dramatic increases in effective treatments and social scientists document greater levels of public acceptance of medical theories about underlying biological and genetic causes of mental illness." 12

Studies also indicate that the mental illness stigma can have an impact not only on an individual's self-esteem, but also quality of life. ${ }^{13}$ In fact, stigma "occupies

9 Martin, K. Jac; Lang, Annie; and Olafsdottir, Sigrun, Rethinking Theoretical Approaches to Stigma, A Framework Integrating Normative Influences on Stigma (FINIS), US National Library of Medicine National Institutes of Health, http://www.ncbi.nlm.nih.gov/pmc/articles/ PMC2587424/.

10 Definition of. "stigma", no. 2., THE OXFORD ENGLISH Dictionary. 2ND EDITION (1989) available at http://www.oed.com/ [accessed on 3 July 2009] as cited by Ferguson, Laura \& Gruskin, Sofia, Using indicators to determine the contribution of human rights to public health efforts, Program on International Health and Human Rights, Harvard School of Public Health (07 July 2009) As cited in Bulletin of the World Health Organization 2009;87:714-719. doi: 10.2471/BLT.08.058321 available at http://www.who.int/bulletin/volumes/87/9/08-058321/en/

11 Definition of "discrimination", no.1. THE OXFORD ENGLISH DICTIONARY. 2ND EDITION (1989) available at http://www.oed.com/[accessed on 3 July 2009]. As cited by Ferguson (2009).

12 Crisp AH, Gelder MG, Rix S, Meltzer HI, Rowlands OJ, Stigmatisation of people with mental illnesses, Br J Psychiatry 177:4-7 (July 2000); Martin JK, Pescosolido BA, Tuch SA, Of fear and loathing: The role of disturbing behavior, labels and causal attributions in shaping public attitudes toward persons with mental illness, Journal of Health and Social Behavior, 41(2):208-233 (2000); Pescosolido BA, Monahan J, Link BG, Stueve A, Kikuzawa S, The public's view of the competence, dangerousness, and need for legal coercion of persons with mental health problems. American Journal of Public Health, 89:1339-1345 (1999); Stuart H, Arboleda-Florez J. Community attitudes toward persons with schizophrenia. Canadian Journal of Psychiatry. 2000;46:245-252 as cited by Martin, K. Jac; Lang, Annie; and Olafsdottir, Sigrun, Rethinking Theoretical Approaches to Stigma, A Framework Integrating Normative Influences on Stigma (FINIS), US National Library of Medicine National Institutes of Health, http://www.ncbi.nlm.nih.gov/pmc/articles/PMC2587424/. 13 Chung, K.F. \& Wong M. C., Experience of stigma among Chinese mental health patients in Hong Kong, Psychiatric Bulletin, 28, 451- 454 (2004) available at http://pb.rcpsych.org/content/28/12/451.full citing Link, B.G., Struening, E. L., Neesetodd, S., et al (2001); The consequences of stigma for the self-esteem of a central place in explanations of low service use, inadequate research funding and treatment infrastructures, and hindered progress toward recovery from mental illness." 14 Society's view detrimentally impacts persons suffering from mental illness, because the implications include withdrawing from treatment and worsening of the condition. ${ }^{15}$ The failure to receive treatment could then lead to great societal costs. ${ }^{16}$ For example, certain untreated mental illnesses, including substance abuse disorders, could lead to increased suicide rates which are projected to be " 1.53 million by the year 2020." 17

In A Call for Action by World Health Ministers, Brundtland identifies "critical strategies to start dispelling the indelible mark, the stigma caused by mental illness." ${ }^{18}$ These strategies are not only necessary, but also practical tactics that can be feasibly implemented in order to prevent suicide and increase quality of life. The list includes:

Public information campaigns using mass media in
its various forms; involvement of the community
in the design and monitoring of mental health
services; provision of support to nongovernmental
organizations and for self-help and mutual-aid
ventures, families and consumer groups; and
education of personnel in the health and judicial
systems and employers ${ }^{19}$

people with mental illnesses. Psychiatric Services, 52, 1621 -1626, Rosenfield, S., Labeling mental illness: the effects of received services and perceived stigma on life satisfaction, American Sociological Review 660 -672, 62 (1997).

14 Estroff SE, Making it crazy: An ethnography of psychiatric clients in an American community, University of California Press; Berkeley, (1981); Markowitz FE, Modeling processes in recovery from mental illness: Relationships between symptoms, life satisfaction, and self-concept, Journal of Health and Social Behavior, 42:64-79 (2001); Sartorius N., Stigma: What can psychiatrists do about it? The Lancet 352:1058-1059 (1998) as cited by Martin, K. Jac; Lang, Annie; and Olafsdottir, Sigrun, Rethinking Theoretical Approaches to Stigma, A Framework Integrating Normative Influences on Stigma (FINIS), US National Library of Medicine National Institutes of Health, http://www.ncbi.nlm.nih.gov/pmc/ articles/PMC2587424/.

15 Chung, Experience of stigma among Chinese mental health patients in Hong Kong, Psychiatric Bulletin 28: 451- 454 (2004) citing Sirey, J. A., Bruce, M. L., Alexopoulos, G. S., et al, Perceived stigma and patient-rated severity of illness as predictors of antidepressant drug adherence, Psychiatric Services 52:1615 -1620( 2001). 16 Id.

17 The World Health Report 2001. Mental Health: New Understanding, New Hope, World Health Organization (2001), as cited by Khan, Murad M, Suicide prevention and developing countries J R Soc Med 98(10): 459-463(October 2005).

18 Brundtland, Gro Harlem, Director General of the World Health Organization, Mental Health: A Call for Action by World Health Ministers 19 (2001), available at http://www.who.int/mental_health/advocacy/en/Call_for_Action_MoH_Intro.pdf.

19 Id. 
Each of these tactics could be an effective tool to increase public awareness and decrease social stigma. However, these strategies are insufficient alone to provide protection to the mentally ill. Specifically, stigma has resulted in four problems which need separate strategies implemented in order to forestall a global mental health crisis. These problems include: (1) Lack of available care, (2) lack of cooperation to acquire the multidisciplinary action necessary to care for the mentally ill, (3) lack of public education and (4) lack of effective mental health policy.

\subsubsection{Lack of Available Care}

The stigma of mental illness prevents the recognition and treatment of disorders that with effective treatments could increase productivity and life satisfaction. ${ }^{20}$ At the $54^{\text {th }}$ World Health Assembly of 2001, neuropsychiatric disorders were responsible for 30.8 percent of all disabilities, and the number is rising. ${ }^{21}$ The Assembly also recognized that depression is expected to be the second leading cause of global burden of disease by 2020.22 The burden further increases as depression rates increase; major depressive disorder is linked to suicide, and the majority of "people who commit suicide are also clinically depressed." ${ }^{23}$ As these illnesses affect not only the person with the illness, but family and friends who surround them, action should be taken immediately in order to provide adequate care and stifle the burden of disease upon us.

Although there is a cross-cultural stigma related to mental illness, the severity varies, and the availability of mental health professionals can fluctuate greatly between countries. For example, Switzerland had a ratio of 42 psychiatrists per 100,000 persons, while the nearby country of Poland reported less than 10 psychiatrists per 100,000 persons in 2009. ${ }^{24}$ And, not only does variance exist between countries, but the shortage of

\footnotetext{
20 See supra note 6.

21 See supra note 18 , at 6.

22 Id.

23 Id.

24 Health at a Glance 2011: OECD Indicators 3.5 psychiatrist, OECD ilibrary, available at http://www.oecd-ilibrary.org/sites/health_ glance-2011-en $/ 03 / 06 /$ index.html;jsessionid $=\mathrm{n} 0 \mathrm{hmk} 5$ pigd $1 \mathrm{k}$. delta? content Type $=\&$ item Id $=/$ content $/$ chapter $/$ health_glance-2011-25-en\&containerItemId=/content/ serial/19991312\&accessItemIds=/content $/$ book $/$ health_glance2011-en\&mimeType $=$ text $/ \mathrm{html}$ (last visited April 5, 2013).
}

mental healthcare practitioners is often exaggerated in rural areas as the available professionals also varies dramatically between urban and rural settings. ${ }^{25}$ For instance, in Australia the ratio of psychiatrist in major cities is 4.6 times that of "remote" regions. ${ }^{26}$

The lack of anonymity in rural settings can create additional problems for those suffering from mental illness. In 1999, the U.S. Surgeon General warned that due to the difficulty of maintaining anonymity, "stigma is particularly intense in rural communities." 27 The stigma in these communities "can lead to under-diagnosis and under-treatment," and the lack of available care can cause additional problems as some persons with mental illnesses spend "more time traveling to see a provider than at actual appointments." 28

\subsubsection{Lack of Multi-Sectoral Cooperation}

Regarding the promotion of global mental health, the World Health Organization has stated that "multi-sectoral action" is needed. ${ }^{29}$ In the Mental Health Policy and Service Guidance Package, the WHO specifies that, "Mental health is necessarily an inter-sectoral issue involving the education, employment, housing, social services and criminal justice sectors. It is important to engage in serious consultation with consumer and family organizations in the development of policy and the delivery of services." ${ }^{30}$ This includes government and non-government organizations, and "the focus should be on promoting mental health throughout the lifespan to ensure a healthy start in life for children and to prevent mental disorders in adulthood and old age." 31

\footnotetext{
25 Id.

26 Id. citing (AIHW, 2010a).

27 Mental Health: A Report of the Surgeon General (1999) as cited in Rural Communities, Substance Abuse and Mental Health Service Administration, SAMHSA's Resource Center to Promote Acceptance, Dignity and Social Inclusion Associated with Mental Health (ADS Center), (last updated June 22, 2012), http:// stopstigma.samhsa.gov/topic/rural/.

28 Id.

29 What is Mental Health, World Health Organization (Sept 3 2007), available at http://www.who.int/features/qa/62/en/index. $\mathrm{html}$

30 Advocacy For Mental Health, Mental Health and Service Guidance Package, World Health Organization, xiii (2003), available at http://www.who.int/mental_health/resources/en/Advocacy.pdf. 31 What is Mental Health (Sept 3 2007).
} 


\subsubsection{Lack of Education}

Ignorance instinctively leads humanity to fear what it does not understand, and the current misunderstanding of mental illness can potentially lead to disastrous consequences.

Just as the lepers of old, the mentally ill are often ostracized by society. ${ }^{32}$ The WHO states that "The image of leprosy has to be changed at the global, national and local levels. A new environment, in which patients will not hesitate to come forward for diagnosis and treatment at any health facility, must be created." 33 Similar to mental illness, the "age-old stigma associated with the disease remains an obstacle to self-reporting and early treatment." 34 Additionally, "the image of leprosy has to be changed at the global, national and local levels" in order to create "A new environment." ${ }^{35}$ One in which patients will not hesitate to come forward for diagnosis and treatment at any health facility." ${ }^{36}$ Education provides that leprosy is currently understood as "not highly contagious" and treatable with multidrug therapy. ${ }^{37}$ As the medical care staff and general public's understanding of leprosy has improved, so has the treatment, decreasing leper numbers.

Education is fundamental in improving treatment of any condition and in preventing bias. In 2003, the WHO released a list of "common misconception" and "how to combat stigma." 38 Some "common misconceptions" of the mentally include that they are "lazy," "unintelligent," "unsafe," "violent," "possessed by demons," "recipients of divine punishment," "untreatable," "in need of hospitalization," "without conscience and unpredictable." 39 Interestingly, in order to combat stigma, the WHO list include many educational interventions. ${ }^{40}$ Some of these interventions involve: "community education on mental disorders," "anti-stigma training for teachers and health workers," "psychoeducation for consumers and families on how to live

32 Leprosy, Media Centre, World Health Organization (September 2012), available at http:/ /www.who.int/mediacentre/factsheets/ fs101/en/.

33 Id.

34 Id.

35 Id.

36 Id.

37 Id.

38 See supra note 30, at 11.

39 Id.

$40 \quad I d$. with persons who have mental disorders," and "education of persons working in the mass media, aimed at changing stereotypes and misconceptions about mental disorders." ${ }^{41}$

\subsubsection{Lack of Mental Health Policy}

David Rosenhan in his famous On Being Sane In Insane Places, indicates the problems of defining the sane and insane. ${ }^{42}$ He states that what is "normal in one culture may be seen as quite aberrant in another." ${ }^{43}$

In 1973, Rosenhan performed an experiment to assess health care providers' ability to distinguish the sane from insane. In the study, eight "sane" people, with no previous psychiatric symptoms, gained admission into twelve psychiatric hospitals of different regions of the United States. ${ }^{44}$ After being admitted with falsified symptoms, the "secret" patients behaved "normal." 45 Hospitalization of the psuedopatients then "ranged from 7 to 52 days, with an average of 19 days." ${ }^{46}$ Rosenhan notes:

Despite their public "show" of sanity, the
pseudopatients were never detected. Admitted,
except in one case, with a diagnosis of
schizophrenia, 8 each was discharged with a
diagnosis of schizophrenia "in remission."
The label "in remission" should in no way be
dismissed as a formality, for at no time during
any hospitalization had any question been raised
about any pseudopatient's simulation. Nor are
there any indications in the hospital records that
the pseudopatient's status was suspect. Rather, the
evidence is strong that, once labeled schizophrenic,
the pseudopatient was stuck with that label.

Also, unlike medical illnesses, a false positive psychiatric diagnosis "carry with them personal, legal, and social stigmas." ${ }^{48}$ Rosenhan retells the injustice stating, "I have records of patients who were beaten by staff for the sin of having initiated verbal contact. During my own experience, for example, one patient was beaten in the presence of other patients for having

\footnotetext{
$41 \quad$ Id.

42 D. L. Rosenhan, Symposium, On Being Sane in Insane Places, 13 Santa ClaraLawyer 379, 379 (1973), available at http:/ / digitalcommons.law.scu.edu/lawreview/vol13/iss3/3.

43 Id.

44 Id. at $380-81$.

45 Id. at 383.

46 Id. at 384.

47 Id.

48 Id. at 385.
} 
approached an attendant and told him, "I like you."",49 Further describing the violations the "committed" endure, Rosenhan states:

The patient is deprived of many of his legal rights by dint of his psychiatric commitment. $2 \mathrm{He}$ is shorn of credibility by virtue of his psychiatric label. His freedom of movement is restricted. He cannot initiate contact with the staff, but may only respond to such overtures as they make. Personal privacy is minimal. Patient quarters and possessions can be entered and examined by any staff member, for whatever reason. His personal history and anguish is available to any staff member (often including the "grey lady" and "candy striper" volunteer) who chooses to read his folder, regardless of their therapeutic relationship to him. His personal hygiene and waste evacuation are often monitored. The water closets may have no doors. ${ }^{50}$

Although the Rosenhan experiment reflects the U.S. mental health care of 1973, still there remains a mistreatment of institutionalized mental health patients. The Rosenhan experiment reveals the need for further legislation to protect those institutionalized, and individuals from unnecessary commitment. Policy-makers should restricting commitment only to those individuals who are a danger to self and others, and protect the rights of those patients who are institutionalized from inhumane and degrading treatment.

Mental health legislation has improved in since 1973, but the World Health Organization reports that still $40 \%$ of states have no mental health policy. ${ }^{51}$ For many of the states with mental health legislation, the policy is outdated. ${ }^{52}$ At this time, there are no universal binding treaties or resolutions regarding the specific treatment of the mentally ill. However, even if there were, the question arises, would these treaties be effective alone, or would they more resemble the other ineffective legislation? In December of 1991, the General Assembly adopted the Principles for the protection of persons with mental illness and the improvement of mental health care, under Resolution 46/119. ${ }^{53}$ Under this non-binding re-

$49 \quad I d$. at 394.

$50 \quad I d$. at 395.

51 Promoting the Rights of People with Mental Disabilities, available at http://www.who.int/mental_health/policy/legislation/1_ PromotingHRofPWMD_Infosheet.pdf (last visited April 5, 2013), citing Mental Health Atlas, World Health Organization (2005).

52 Id.

53 Principles for the protection of persons with mental illness and the improvement of mental health care, Office of the High Commissioner for Human Rights, available at http://www.equalrightstrust.org/ertdocumentbank/UN_Resolution_on_protection_ of_persons_with_mental_illness.pdf (last visited April 4, 2013). solution, principle one articulates the standard of "best available mental health care," available to "all persons." 54 This is the ideal standard, but binding legislation must be enacted to promote the availability of the "best" mental healthcare to all persons.

The WHO has also affirmed that, "mental health policies and plans for their implementation are essential for coordination of services and activities to improve mental health and reduce the burden of mental disorders." ${ }^{55}$ The need for further policy enactment is evident, but this is insufficient alone. As social movements increase awareness of mental illness, stigma decreases, and access to treatments increases. Through increased education, and through a cooperative multi-sectoral approach the quality of care will also increase. As these changes occur, the effect of new policy will be more efficient and society will take less time to adapt. In many cases, for lack of incentive, many governments will not be persuaded to pass new regulations without some form of activism or pressure from the international community. Additionally, once the regulations are passed, activism will be necessary in order to prevent a repeat of the U.S. desegregation laws there must be some pressure or incentive to implement the new regulations.

\section{Cross-cultural stigmatization: Examples OF "DEVELOPED" AND "DEVELOPING" WORLD}

\subsection{Current Problems within Developing Nations}

\subsubsection{Government Spending and Poverty}

Although human rights violations occur throughout the world, people within developing nations are especially susceptible to mental health abuses. Studies have found a positive correlation between mental health and poverty indicators such as: income, material possessions, and education. ${ }^{56}$ In ten stand-alone studies,

54 Id. at Principle 1(1).

55 Saxena, S., Thornicroft, 878 (2007) citing Mental health policy, plans and programmes, World Health Organization (2004).

56 Patel, Vikram \& Kleinman, Arthur, Poverty and common mental disorder in Developing Countries, Bulletin of the World Health Organization 81 (8) 609, 609-10(2003), available at http://www.who.int/ 
there was especially high correlation between education level and prevalence of common mental disorders. ${ }^{57}$ The dearth of skilled providers is especially prevalent in low-income countries. Reports indicate that "low-income countries" have proportions as low as " 0.05 psychiatrist and 0.42 nurses per 100,000 people. [While] The rate of psychiatrist in high income countries is 170 times greater and for nurses 70 times greater." ${ }^{\text {58 }}$

Government spending on mental health in most countries is lower than needed, but the poorer the countries the lower the percentage of healthcare spending put towards mental health. ${ }^{59}$ Within all countries, the lowest socioeconomic populations have the highest incidence of mental illness, and the least available care. ${ }^{60}$ These problems need to be addressed; however, the greater problem is not just in the lack of available care or the omission of care, but affirmative violations of human rights.

\subsubsection{An Example from Ghana}

A report of human rights abuses of the mentally ill in Ghana found that family members are the individuals who typically send the mentally ill to receive care. ${ }^{61}$ These individuals are customarily sent to either a hospital or prayer camp to receive treatment. ${ }^{62}$ The prayer camps are founded to give support by church organizations, while the hospitals can provide institutionalization. Human Rights Watch ("HRW") tells the story of Doris, who at twenty-two was taken to a prayer camp by her father and was treated for demons. ${ }^{63} \mathrm{HRW}$ reports some of her circumstances over the course of years, including being "tethered by a rope to a wall for about two months, forced to fast for days at a time, and left to sleep, bathe, and defecate in the open." ${ }^{64}$

bulletin/volumes/81/8/en/Patel0803.pdf (last visited March 15, 2013).

57 Id. at 610.

5810 Facts on Mental Health, (Fact 8), World Health Organization, available at http://www.who.int/features/factfiles/mental_health/mental_health_facts/en/index $7 . h t m l$ (last visited April 5, 2013).

59 Saxena, S., Global Mental Health 2-Resources for mental health: scarcity, inequity, and inefficiency, 878 (2007).

60 Id. at 878.

61 Like a Death Sentence, Abuses against Persons with Mental Disabilities in Ghana, Human Rights Watch 1 (2013), available at http://www.hrw.org/reports/2012/10/02/death-sentence.

62 Id. at 2.

63 Id.

64 Id.
Like Ghana, in many regions the majority of the people believe that mental illness is caused by evil spirits or demons; thus, the health treatment can differ significantly from conventional medicine. ${ }^{65}$ In addition to the lack of proper treatment, there is little access to treatment. With an estimated 2.8 million suffering from mental illness in Ghana, the entire country has only twelve practicing psychiatrist, and very little access to outpatient therapy. ${ }^{66}$

\subsection{Current problems within Developed Nations}

\subsubsection{Statistics within the United States}

Although human rights violations of the mentally ill are prevalent in developing countries, many developed countries have similar problems. A 2009 study found that 26.4 percent of the population of the United States could be diagnosed with a mental illness at any given time. ${ }^{67}$ By comparison, in china the number is roughly 17.5 percent. ${ }^{68}$ The U.S. Center for Disease Control ("CDC") reports that only $17 \%$ of the population is within a state of optimal mental health. ${ }^{69}$

\subsubsection{Discrimination in the United Kingdom}

A survey response of 556 people in the United Kingdom who received psychiatric treatment, found that " $56 \%$ experienced discrimination within the family, $51 \%$ from friends, $47 \%$ in the workforce and $44 \%$ from general practitioners." ${ }^{70}$ Although the survey could in-

65 Id.

66 Id.

67 China Tackles Surge in Mental Illness, nature 468, 145 (Published online November 10, 2010), corrected 17 November 2010, available at http://www.nature.com/news/2010/101110/ full/468145a.html citing The WHO World Mental Health Survey Consortium, J. Am. Med. Assoc. 291, 2581-2590 (2004)

68 China Tackles Surge in Mental Illness, nature 468, 145 (Published online November 10, 2010), corrected 17 November 2010, available at http://www.nature.com/news/2010/101110/ full/468145a.html citing M. R. Phillips et al, Lancet 373, 2041-2053 (2009).

69 Mental Health Basics, Center for disease Control and Prevention, available at http://www.cdc.gov/mentalhealth/basics.htm (last visited March 18, 2013). See Note 2, Mental Health: A Report of the Surgeon General, U.S. Department of Health and Human Services, Substance Abuse and Mental Health Services Administration, Center for Mental Health Services, National Institutes of Health, National Institute of Mental Health (1999).

70 Chung, Experience of stigma among Chinese mental health 
dicates bias due to the return rate of 13 percent, these numbers are still very high, indicating at least a portion of society experiences bias towards those who use the mental health system. ${ }^{71}$

\subsubsection{Prisons in the United States}

Within the United States the prison system is overrun by the mentally ill. Yet, within this system, the inmates are often unable to obtain therapy and can be placed in solitary confinement. These conditions can potentially worsen the illness and cause additional public safety problems as many individuals leave jail without receiving therapeutic care. For example, solitary confinement has reportedly increased within the United States as a mechanism to cope with difficult and dangerous prisoners. ${ }^{72}$ Solitary confinement is a hazardous practice and "recognized as difficult to withstand; indeed, psychological stressors such as isolation can be as clinically distressing as physical torture." ${ }^{73}$

According to news sources, in April of 2013, "U.S. District Judge Lawrence Karlton in Sacramento ruled that the state failed to prove that it is providing the level of care required by the U.S. Constitution for the state's more than 32,000 mentally ill inmates." ${ }^{74}$ According to Time magazine, California has historically been known for the defective prison system. ${ }^{75}$ In 1991, the original suit was initiated under the premise that life within the prisons violated the constitution as "cruel and unusual punishment." 76 Although officials have recognized improvements in the system since that time, Judge

patients in Hong Kong, Psychiatric Bulletin 28: 451- 454 (2004) citing Pull Yourself Together: A Survey of the Stigma and Discrimination Faced by People Who Experience Mental Distress, Mental Health Foundation (2000).

71 Id.

72 Metzner, Jeffrey L., \& Fellner, Jamie, Solitary Confinement and Mental Illness in U.S. Prisons: A Challenge for Medical Ethics, J Am Acad Psychiatry Law 38:1:104-108 (March 2010), available at http://www.jaapl.org/content/38/1/104.full.

73 Id. citing Reyes $\mathrm{H}$, The worst scars are in the mind: psychological torture, Int Rev Red Cross 89:591-617 (2007); Basoglu M, Livanou M, Crnobaric C, Torture vs. other cruel, inhuman and degrading treatment: is the distinction real or apparent? Arch Gen Psychiatry 64:277-85 (2007).

74 Feds Retain Control of Calif. Prison Mental Health, Associated Press, Time (April 5, 2013), available at http://nation.time. com/2013/04/05/feds-retain-control-of-calif-prison-mentalhealth/.

75 Id.

76 Id.
Karlton's ruling cited the continued inability to lower prisoner's suicide and maintain adequate staff. ${ }^{77}$

\section{WHY IS MENTAL HEALTH DIFFERENT FROM other Human Rights violations?}

When the laws are implemented, many do not find the treatment of mentally ill wrong. These are people with "demons" after all. The UN World Health Organization ("WHO'), reports that:

Misunderstanding and stigma surrounding mental ill health are widespread. Despite the existence of effective treatments for mental disorders, there is a belief that they are untreatable or that people with mental disorders are difficult, not intelligent, or incapable of making decisions. This stigma can lead to abuse, rejection and isolation and exclude people from health care or support. Within the health system, people are too often treated in institutions which resemble human warehouses more than places of healing. ${ }^{78}$

Although legislative changes are necessary for improved care of the mentally ill, these reforms alone are insufficient to safeguard against further violations. In A Call for Action by World Health Ministers, the authors articulate this important point.

\begin{abstract}
Introducing legislative reforms that protect the civil, political, social, economic, and cultural entitlements and rights of the mentally ill is also crucial. However, this step alone will not bear the fruits expected by legislators without a concerted effort to erase stigmatization as one of the major obstacles to successful treatment and social reintegration of the mentally ill in communities. ${ }^{79}$
\end{abstract}

The current maltreatment of many individual suffering from mental illness is so entrenched in society, even thought of as necessary, that mental health legislation without a societal backing would be unenforceable de facto rules.

77 Id.

78 End human rights violations against people with mental health disorders, December 10: International Human Rights Day, World Health Organization (News releases 2005), available at http://www. who.int/mediacentre/news/releases/2005/pr68/en/index.html (last visited March 15, 2013).

79 Brundtland, Gro Harlem, Director General of the World Health Organization, Mental Health: A Call for Action by World Health Ministers 19 (2001), available at http://www.who.int/mental_health/advocacy/en/Call_for_Action_MoH_Intro.pdf 
Some problems or human rights violations can be regulated strictly by the change in domestic laws or policies. However, mental health problems occur in every socioeconomic class, culture, and country. This stigma, unlike many social stigmas, is associated at differing degrees of severity, but cross-culturally. When articulating policies for anti-corruption and genocide, or even gender equality, the impact of these violations can depend upon cultural stigmas. However, when cross-cultural persecution occurs, the situations of those burdened has historically improved through social movements. Many movements have taken years to develop, but when the general public is educated on a problem, governments are pressured to sign conventions, pass legislation, and then enforce the laws. Taking the opportunity to learn from history, a social movement should be implemented.

\section{Social Movement Theory}

In the book, The Social Movement Society, social movements are defined as "collective challenges to existing arrangements of power and distribution by people with common purposes and solidarity, in sustained interaction

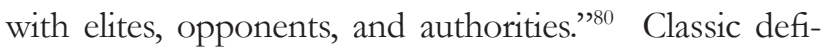
nitions include a "desire for change." ${ }^{\text {81 }}$ Multiple studies have indicated that organizational changes are the direct result of social movement activism. ${ }^{82}$ Burgmann states

80 The Social Movement Society, Contentious politics for a new century, 3 (Meyer, David S. \& Tarrow, Sidney G. eds., 1998), google books available at http://books.google.com/books?id=D5_ kahOwxaEC\&printsec $=$ frontcover\&dq $=$ tarrow + social + movem ents\&hl $=$ en\&sa $=\mathrm{X} \& \mathrm{ei}=\mathrm{xo} 9 \mathrm{cUdnJEKiMigLv}-\mathrm{YDoCw} \& v e d=0$

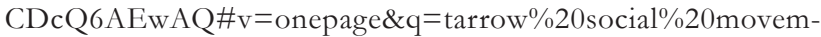
ents\&f $=$ false.

81 How social movements matter. Berstein, Paul, Ch. 1: social movements and public policy, Vol. 10. U of Minnesota Press, 7 (Giugni, Marco, Doug McAdam, \& Charles Tilly eds., 1999) available at http://books.google.com/books?hl=en\&lr=\&id=URFq34yxCaYC \&oi $=$ fnd\&pg $=$ PR $7 \& d q=$ Tilly + social + movements\&ots $=$ WA 4 U4Y PgDp\&sig=AOAaytJfyQJQPTU0kUPqGULhir4, citing McCarthy and Zald, 1217-18(1977); Tilly 305 (1984).

82 Social Movements, Risk Perceptions, and Economic Outcomes: The Effect of Primary and Secondary Stakeholder Activism on Firms' Perceived Environmental Risk and Financial Performance, AMERICAN SOCIOLOGICAL REVIEW 77(4): 573-596, 573 (2012), available at http:/ /asr.sagepub.com/ content/77/4/573.full, citing Lounsbury Michael, Cultural Entrepreneurship: Stories, Legitimacy, and the Acquisition of Resources, STRATEGIC MANAGEMENT JOURNAL 22:545-64(2001); Hayagreeva, Rao \& Market Rebels: How Activists Make or Break Radical Innovations, Princeton University Press (2009); Schurman, Rachel \& Munro, William, Targeting that as globalization of politics and institutions takes place, so too must the social movements become global. ${ }^{83}$ That the success of certain movements is determined not only by the ability to pressure politicians for change, but the ability to change perceptions of the problem. ${ }^{84}$

In sum, the fundamental idea of "social-movement" is that through highly motivated activist, those who care about the cause, but are less ardent will too become motivated to promote change. ${ }^{85}$ This activism leads to a domino effect that promotes change, and brings awareness of the problem to the public as a whole. However, even if there are activists, for the social movement to become a collective action social ties must exist. ${ }^{86}$ The difference between activists solely protesting and the power of a 'social movement' is the ability to achieve networks and mobilization.

Capital: A Cultural Economy Approach to Understanding the Efficacy of Two Anti-Genetic Engineering Movements, AMERICAN Journal of SOCIOLOGY 115:155-202 (2009); Sine, Wesley \& Lee, Brandon, Tilting at Windmills? The Environmental Movement and the Emergence of the U.S. Wind Energy Sector, ADMINISTR ATIVE SCIENCE QUARTERLY 54:123-55 (2009); Soule, Sarah, Contention and Corporate Social Responsibility, Cambridge University Press (2009); Vasi, Ion Bogdan, Social Movements and Industry Development: The Environmental Movement's Impact on the Wind Energy Industry, MOBILIZATION: AN INTERNATIONAL JOURNAL 14:31536 (2009); Vasi Ion Bogdan, Winds of Change: The Environmental Movement and the Global Development of the Wind Energy Industry, Oxford University Press (2011); Zald Mayer, Morrill Calvin \& Rao, Hayagreeva, The Impact of Social Movements on Organizations: Environment and Responses, Social Movements and Organization Theory, Cambridge University Press 253-79 (Davis G., McAdam D., Scott R., Zald M.. eds., 2005).

83 Burgmann, Verity, Power, Profit, and Protest: Australian Social Movements and Globalisation 2-3 (2003), available at http:/ / books. google.com/books?id=atpiAdA9IEMC\&printsec $=$ frontcover\&dq $=$ indigenous + rights + social + movement $\& \mathrm{hl}=$ en $\&$ sa $=X \&$ ei $=4 \mathrm{Wde}$ UfemKoL4yQGJ44CgBw\&ved=0CDoQ6AEwAQ

84 Social Movements, Risk Perceptions, and Economic Outcomes: The Effect of Primary and Secondary Stakeholder Activism on Firms' Perceived Environmental Risk and Financial Performance, American Sociological Review 77(4): 573-596 (2012). (Authors discussing within context of environmental activism, "The influence of environmental activism - and, more generally, of any type of social movement activism-results not only from activists' pressure on corporations to adopt certain practices, but also from activists' ability to change perceptions about a firm's behavior, potentially altering a firm's image, reputation, and risk profile.”).

85 Oliver, Pamela E. \& Gerald Marwell, Mobilizing Technologies for Collective Action, Frontiers in social movement theory, 251 (Morris, Aldon D. \& Mueller, Carol Mclurg eds., 1992) available at http://www.ssc.wisc.edu/ oliver/PROTESTS/ArticleCopies/OliverMarwell1992MobilizingTechnologies.pdf.

86 Diani, Mario \& McAdam, Doug, Social movements and networks: Relational approaches to collective action, Oxford UnIverSity Press on Demand (2003) (Author states that "collective action is significantly shaped by social ties). 


\subsection{Relative Deprivation}

\subsubsection{Perception and Actual Opportunity}

According to McAdam, there exists a strong correlation between "subjective perception and structure of opportunities." ${ }^{87}$ In fact, it was due to a change in federal policies that created the positivism of the civil rights movements in the $1930 \mathrm{~s}$ and $60 \mathrm{~s}{ }^{88}$ In the late $1960 \mathrm{~s}$ when opportunities began to decrease, the perception of this decrease also occurred. ${ }^{89}$ According to "Tarrow, people join in social movements in response to political opportunity." 90 Yet, "Political opportunities are both seized and expanded by social movements, turned into collective action and sustained by mobilizing structures and cultural frames." ${ }^{\prime 1}$ As this principle of necessary opportunities is applied, the law has a fundamental purpose in creating an increase of opportunities in a positive feedback loop. However, the opportunity does not need to be great; Tarrow also explains that the original protestors can create optimism as they "make evident" opportunities not previously discernible. ${ }^{92}$

\subsection{Authority}

In the late 1800s, sociologist Max Weber developed a theory of three types of authority that movements rely on to gain success. Morris and Staggenborg describe a movement leader as a "strategic decision-makers who Inspire[s] and organize[s] others to participate in social movements." 93 The leader has two fundamental roles, functioning as an internal "mobilizer" to make things happen, and an external "articulator" so that the

87 Kurzman, Charles, The social movements reader: cases and concepts. Vol. 12, 5 Wiley-Blackwell, 42 (Goodwin, Jeff \& James M. Jasper, eds., 2009), available at http:/ / books.google.com/books?hl=en\&lr= \&id $=$ Wq5ELSlaZlgC\&oi $=$ fnd $\& p g=P P 12 \&$ dq $=$ relative + deprivatio $\mathrm{n}+\mathrm{in}+$ social + movements\&ots $=1 \mathrm{QCWfV} 7 \mathrm{dU} 4 \&$ sig $=\mathrm{tCvIJG} 5 \mathrm{hWV}$ N9C3GoGAT3KQMm'Trk, citing McAdam (1982).

88 Id. Citing McAdam (1982 at 83-86, 108-110, and 156-163).

89 Id. citing McAdam at page 202.

90 See Goodwin 42, citing Tarrow 17 (1994).

91 Woliver, Laura R., Review of Sidney Tarrow 'Power in Movement: Social Movements, Collective Action, and Politics', The Journal of Politics 57, 1206-1207 (1995), see also text cited from Tarrow 251(1994).

92 See Goodwin 42 citing to Tarrow 96-97 (1994).

93 Morris, Aldon, Leadership in Social Movements Aldon Morris and Suzanne Staggenborg, 1 (2002), available at http://www.sociology. northwestern.edu/people/faculty/documents/Morris-Leadership. pdf. outside world legitimizes the cause. ${ }^{94}$ Without authority the movement will not progress as there are specific instances when leadership is critical to the success of a movement. $^{95}$

\subsubsection{A charismatic leader}

Within movement leaders is a "subset," referred to as charismatic leaders. These are they who "represent revolutionary social forces" that "are responsible for significant societal transformations." "96 These leaders, "by the force of their personal abilities are capable of having profound and extraordinary effects on followers," matic leader as one who possesses superhuman qualities and accept unconditionally the leader's mission and directives for action." 98 Many past social movements have relied upon charismatic leaders to propel individual activist into action.

\subsubsection{Rational Authority/Bureaucratic Authority}

According to Weber, the belief in bureaucratic authority stems from normative rules when individuals are formally appointed or elected under these rules. ${ }^{99}$ This is a common form of governing recognized by West, essential to global movements in order to propel legislation and promote safeguards to its enforcement.

\subsubsection{Traditional Authority}

Often recognized as patriarchal leadership within families, the traditional authority model is a result of custom and respect. Recognized commonly in indigenous cultures, traditional authority can at times conflict with state authority. For example, Lungisile Ntsebeza

\footnotetext{
$94 \quad I d$. at 2.

95 Id.

96 Conger, Jay A. \& Rabindra N. Kanungo, Toward a behavioral theory of charismatic leadership in organizational settings, ACADEMY OF MANAGEMENT REVIEW 637, 637(1987), available at http://www.jstor.org/di scover $/ 10.2307 / 258069$ ?uid $=3739928$ \&uid $=2 \&$ uid $=4 \&$ uid $=37392$ $56 \&$ sid $=21102168162797$ citing House and Baetz, 399 (1979).

97 Id.

98 Conger, 637 citing Willner 1984.

99 Max Weber, available at http://business.nmsu.edu/ dboje/ teaching/503/weber_links.html (last visited August 20, 2013) (referencing Weber, Max The Theory of Social and Economic Organization. (1947 Translated by A. M. Henderson \& Talcott Parsons 1947), See also Weber, Max, Three types of Legitimate rule, 3.
} 
writes that rural South Africa should take "into account the incompatibility of democratic decentralization and hereditary rule that underlines traditional authority." 100

\subsection{Mobilization}

According to Doug McAdam, a number of factors and processes facilitate mobilization. ${ }^{101}$ These factors, such as political opportunity, can lead to different methods of mobilization. ${ }^{102}$ In his book, Social Movements and The Legal System, Joel Handler states the ability "to mobilize resources depends primarily on size, on its ability to attract elite support, or on its capacity to provide meaningful selective incentives to its leaders and staff. ${ }^{103}$ There are however, problems when attempting to promote a selective good as opposed to a collective good which would benefit society as a whole. ${ }^{104}$ Specifically, mobilizing resources and support from those who view the benefit is immaterial for oneself. ${ }^{105}$ Some individuals join organizations for solidarity or for a sense of satisfaction when the benefits go to the larger society or groups other than the joiner,"106 but "the most powerful incentives are material ones." 107

Historically, some movements and organizations have relied upon different techniques to acquire support, mobilize resources, and maintain effectiveness. Some organizations rely upon mass memberships where the incentive to join is small, but the participation is minimal, usually including a small yearly membership

100 Ntsebeza, Lungisile, Democratic decentralisation and traditional authority: Dilemmas of land administration in rural South Africa, The European Journal of Development Research 16.1, 7189, 81 (2004), available at http://pdf.wri.org/eaa_decentralization_ ejdr_final_chap5.pdf.

101 Comparative Perspectives on Social Movements: Political Opportunities, Cambridge Un Press, 26 (McAdam, Doug, McCarthy, John, D. \& Zald, Mayer N. eds., May 1996), available at http:// books.google.com $/$ books?hl=en\&lr $=\& i d=8 \mathrm{UamWMisjtkC \& oi=f}$ $\mathrm{nd} \& \mathrm{pg}=\mathrm{PR} 7 \& \mathrm{dq}=$ mobilization + in + social + movements\&ots $=\mathrm{Dt}$ Uz1_kwxg\&sig=krEA1SYjdSS4B_qgZc1MiNs8cMo\#v $=$ onepage $\& q=$ mobilization $\% 20 \mathrm{in} \% 20$ social $\% 20$ movements $\& f=$ false.

102 Id.

103 Handler, Joel, F., Social Movements and the Legal System, A Theory of Law Reform and Social Change, 5 (1979).

$104 I d$., see generally, discussion of Olson's theory of collective good and selective good, and the need to overcome "free riders."

105 Id. at 7.

106 Id.

107 Id. See Gamson quote, 60-66 (1975) “organizations that are successful in supplying material selective incentives have the best success rates." fee. ${ }^{108}$ For example, a common technique employed in "funded social movement organizations," includes providing prestige and career development as selective incentives for leadership while support is provided by nonmembers. ${ }^{109}$ With professional full-time staff, these leaders "use the media to attract members, gather support, and influence elites." 110 This however can be "unstable," as the majority of contributors "do not directly experience the grievances of the group; their relationship is tenuous" as they pay "for the collective goods but [who] do not consume them."

\subsection{Globalization}

Sidney G. Tarrow explains that "globalization from below" will be a slow process he describes as "transnational contention." "111 Below he defines the five emerging methods of "transnational contention."

- Domestication: the use of internal protest tactics that pressure national governments to defend people's interest

- Global framing: the framing of domestic issues in broader terms than their original claims would seem to dictate

- Transnational diffusion: the spread of similar forms of action and similar claims across borders

- Externalization: domestic actors targeting external actors in attempts to defend their interests

- Transnational coalition formation: the creation of transnational networks to support cooperation across borders ${ }^{112}$

As movements rely upon these methods, globalization can occur, even if the process at times yields results slowly.

\footnotetext{
108 Id. See generally example Common Cause at 9.

109 Id. at 8.

110 Id.

111 Tarrow, Sidney G., Power in Movement, Social Movements and Contentious Politics, $3^{\text {rd }}$ ED., 235 (2011).

112 Id., See Lanham, MD: Rowman \& Littlefield (transnational coalition formation, text includes citation to. Coalitions Across Borders: Transnational Protest and the Neoliberal Order. (Bandy, Joe and Jackie Smith, eds., 2004).
} 


\section{HISTORY OF SOCIAL MOVEMENTS}

Historically, mental illness is not the only injustice provoked by cultural stigma. Physical disabilities, race, and gender have all benefited from social movements to increase awareness of the immorality of stigma induced unfair and unequal treatment. These social movements can take years to progress, but have dramatically changed human rights. An example of an effective social movement is the global Indigenous movement which will be discussed and compared below.

\subsection{Indigenous Social movement}

In 1957, the first international convention specific to indigenous persons was adopted by the International Labor Organization ("ILO") "at the request of the UN-System."113 This Convention No. 107 was a step in the right direction, but embraced an "integrationist approach," which did not preserve the indigenous right to self-determination and failed to preserve language and culture. ${ }^{114}$ Then in 1989, ${ }^{115}$ the ILO adopted Convention No. 169, which as of August 2013, has been ratified by 20 countries. ${ }^{116}$ Unlike Convention 107, 169 incorporated a conservationist approach in order to protect the valued rights and customs of indigenous persons. ${ }^{117}$

Convention 169 was once again a step in the right direction, but still insufficient protection. Augusto Willemsen Diaz states that from 1977 onward, relying "on enthusiastic, devoted, brilliant and effective struggle of indigenous peoples and their members, as well as on the international indigenous movement that was forming and growing around the task," pursued "obtaining recognition of indigenous peoples. . . along with their human rights and fundamental freedoms. .."118 During the United Nations Decade for Indigenous Peoples (19952004), transnational organizations sought "recognition

113 International Labour Organization, Convention No. 107 (1996-2013) available at http://www.ilo.org/indigenous/Conventions/no107/lang--en/index.htm.

114 Id.

115 Id.

116 International Labour Organization, Convention No. 169 (1996-2013), available at http://www.ilo.org/indigenous/Conventions/no169/lang--en/index.htm.

117 Id.

118 Making the Declaration Work, IWGIA, 18 (Charters, Claire \& Stavenhagen, Rodolfo eds., December 2009), Available for PDF download http://www.iwgia.org/publications/searchpubs?publication_id=11. and rights" for indigenous peoples specifically related to "property and possessions (such as territories, resources, material culture, genetic material, and sacred sites), practices (cultural performances, arts, and literature), and knowledge (cultural, linguistic, environmental, medical, and agricultural)." 119 Then finally, in September 2007, the United Nations adopted the United Nations Declaration on the Rights of Indigenous Peoples by a vote of 144 States. ${ }^{120}$

Scholars describe the success through both a top-down and bottom-up approach. Lillian Aponte Miranda describes this "macro-level" scenario, stating that "a narrative of indigenous peoples' role in international lawmaking defies a "top-down/bottom-up" dichotomy. Indigenous peoples' participation reflects a bottom-up transnational social movement that engages both informal mechanisms of knowledge production and norm-generation and formal, top-down decision-making structures with the aim of establishing indigenous peoples' distinctiveness." 121

As a means of furthering such resistance to local
circumstances, these communities engage informal
mechanisms of transnational knowledge production
such as transnational networks and non-governmental
organizations. They further engage formal channels of
decision-making through advocacy before international
and regional human rights bodies. Indigenous
communities' multi-layered participatory efforts focus
on strategically identifying core indigenous norms and
values that distinguish indigenous communities from
other groups. These efforts serve as a foundation for
the recognition of a distinctive transnational identity
and framework of rights.

Describing the involvement of individual communities, Aponte indicates that many indigenous communities engage "in bottom-up resistance against affronts to their way of life through participation in informal norm-building processes." 123 These communities worked in conjunction with "transnational networks

119 Hodgson, Dorothy L, Introduction: Comparative perspectives on the indigenous rights movement in Africa and the Americas, American Anthropologist 104.4, 1037, 1037 (2002), available at http://graduateinstitute.ch/webdav/site/mia/shared/mia/cours/ IA010/Hodgson $\% 202002 \% 20$ intro.pdf.

120 Wiessner, Siegfried, Audiovisual Library of International Law, United Nations Declaration on the Rights of Indigenous Peoples, New York, (13 September 2007), available at http://untreaty. un.org/cod/avl/ha/ga_61-295/ga_61-295.html.

121 Lillian Aponte Miranda, Indigenous Peoples As International Lawmakers, 32 U. Pa. J. Int'l L. 203, 213 (2010)

122 Id. (discussing communities such as "Awas Tingni in Nicaragua, U'wa in Colombia, and Western Shoshone in the United States").

123 Id at 228. 
and non-governmental organizations dedicated to the production of knowledge and generation of norms regarding the recognition of a distinctive transnational indigenous identity and a derivative framework of indigenous rights." ${ }^{24}$ However, communities have also mobilized "through participation in more formal, institutionalized, top-down structures that contribute to the development of norms and decision-making regarding indigenous peoples' rights." 125 Through both the "formal" and "informal" processes have the indigenous rights movement rendered success through contributing "to the formulation of "hard" and "soft" law" principles applicable to indigenous peoples." 126

Aponte further states that "through a transnational social movement that has capitalized upon the politics of difference, indigenous peoples have participated significantly in the construction of a distinctive international, legal identity and derivative framework of human rights." ${ }^{27}$ The indigenous rights movement has effectuated worldwide change. There are still innumerable violations of rights, but this movement has facilitated great improvement and is regarded as a success by the international community.

Although a global change has taken root, the process was slow. For example, in the 1920s the Australian movement began when an aborigine man named Anthony Martin Fernando, moved to Europe and began protesting the inequality in Australia. ${ }^{128}$ It took forty years, but in 1967, "90 per cent of Australians voted in a referendum in favor of removing references in the Australian constitution that discriminated against Aboriginal people." ${ }^{129}$ Although Anthony Fernando did not live to see success, future activist were inspired by his work. ${ }^{130}$ In this case it was "not the government," but the ordinary people who decided to change things. ${ }^{131}$

\section{Id.}

125 Id.

126 Dinah Shelton, Normative Hierarchy in International Law, 100 AM. J. INT'L L. 291, 319-23 (2006) (discussing the "dynamic interplay" between "hard law" and "soft law") as cited note 10, 81 by Lillian Aponte Miranda, Indigenous Peoples As International Lawmakers, 32 U. Pa. J. Int'l L. 203, 228 (2010).

127 Lillian Aponte Miranda, Indigenous Peoples As International Lawmakers, 32 U. Pa. J. Int'l L. 203, 205 (2010)

128 Australian geographic, The Fight for Aboriginal Civil Rights, (May 25, 2010), available at http://www.australiangeographic.com. $\mathrm{au} /$ journal/indigenous-civil-rights.htm

129 Id.

130 Id.

131 Id. quoting an interview of Jay Arthur (curator of a Mel-

\section{Mental Health Social Movements}

Social movements have the potential to impact human rights violations of the mentally ill, because social movements have the capacity to revolutionize when developed across multiple states. ${ }^{132}$ According to the WHO, as mental health advocacy movements have developed in countries such as Australia, Canada, Europe, New Zealand and others, it has helped to change society's perceptions of persons with mental disorders. ${ }^{133}$ In 2003, the WHO also reported that current movement "comprises a diverse collection of organizations and people with various agendas [, and] although many groups join together to work in coalitions or to achieve common goals, they do not necessarily act as a united front." ${ }^{\prime 134}$ However, although many developed countries have begun the formation of social movements, many developing countries have only infant mental health advocacy groups or have yet to form any. ${ }^{135}$ Yet, even if the movements have not begun, there exist a "potential for rapid development, particularly because costs are relatively low, and because social support and solidarity are often highly valued in these countries." "136 In order to realize the potential within these societies, "technical assistance and financial support from both public and private sources" are likely needed. ${ }^{137}$

Although indigenous peoples have not traditionally had equal access to justice and due to language and cultural barriers, there are individuals within indigenous communities who have successfully self-advocated. Also similar to the disability movement, persons suffering from severe mental illness would theoretically have difficulty advocating justice. The institutionalized mentally ill will be more productive with the assistance of others. Likely relying even more on outside assistance than indigenous persons who often advocated on their own behalf through NGOs and systems of government.

bourne, Australia), From Little Things Big Things Grow, (Exhibition on Aboriginal Rights).

132 Castells, Manuel, The City and Social Movements, Human Geography 2 available at http://socgeo.ruhosting.nl/html/files/ geoapp/Werkstukken/Castells2.pdf (Last visited April 4, 2013), citing Tarrow, S.G. Power in movement: social movements and contentious politics (Cambridge 1998).

133 Supra note 30 , at 3.

134 Id.

135 Id.

136 Id

137 Id. 


\subsection{United States Movement}

An example of budding changes occurred in the United States. In the 1950s proponents of mental health reform within the United States instituted litigation to promote the right to treatment. ${ }^{138}$ This litigation protected involuntarily committed individuals from going to prison when they had not committed a crime; affording these the right to receive psychiatric treatment. ${ }^{139}$ In the 1970s Wyatt v. Stickney140 eventually led to hearings where courts adopted standards that included requirements such as the "right to privacy and dignity." 141 Studies found that there was a "was a significant increase in public expenditures for mental health, and this was directly attributable to the litigation," along with "great improvement in the personal cleanliness of the patients and the sanitary conditions of the facilities and 'most life-endangering conditions were removed." ${ }^{142}$ The Wyatt circumstances were distinctive, the judge was an activist and he appointed a unique Human Rights Committee to oversee the defendant institutions. ${ }^{143}$ These were "extraordinary," "non-traditional" measures, but the scenario is still applicable as evidence that feasible changes in mental healthcare can occur under prejudice circumstances. ${ }^{144}$ Finally, Handler notes that the mental health law reformers did not have favorable circumstances, that unlike the civil rights lawyers, "there were no groups to which the lawyers could belong," and although these persons had the "legal expertise," they had "no expertise or resources in the enforcement stage." 145

\subsection{How to implement a Mental Health Social Movement}

Similar to the indigenous movement, through both a "top-down" and "bottom-up" approach, the mentally ill could advocate in order to formulate both "'hard' and 'soft' law principles."'146

\footnotetext{
138 Supra note 102 , at 167.

139 Id.

140 Wyatt v. Stickney, 344 F. Supp. 373, 344F Supp. 387 (M.D. Ala. 1973 ) enforcing 325 F. Supp. 781, 334 F. Supp. 1341, aff'd. in part. 503 F.2d 1305 (5 ${ }^{\text {th }}$ Cir. 1974). As cited by Handler, note 13 at 167.

141 Supra note 95 , at 168.

142 Id.

143 Id.

144 Id.

145 Id. at 175.

146 See Supra note 125.
}

\subsubsection{Actual Opportunity}

Similar to mentally ill individuals, indigenous peoples have traditionally been inflicted by injustice. ${ }^{147}$ However, the public must become aware of the Relative Deprivation between those perceived as mentally healthy and those with mental health problems. As Tarrow states, the opportunity need not be great, but as opportunities present there will be a positive-feedback loop. Recently, as the disabilities movement has resulted in some success, the moment to "make evident" the available opportunities for change has arrived. ${ }^{148}$

\subsubsection{Leadership and Authority}

In order to implement a global social movement there must be "strategic decision-makers who Inspire[s] and organize[s] others to participate in social movements."149 There can exist more than one leader; however, there must be leadership in order to "articulator" the cause of the mentally ill, and to gain and retain support for the movement. ${ }^{150}$

According to the Weber paradigm, this movement would be the most successful if all three types of leadership were included. For example, a charismatic leader would act as a voice of the mentally ill, one who could articulate the problems to gain support of the general public. A charismatic leader could also benefit a mental health movement in order to unify the bureaucratic and traditional societies. However, rational authority would also be beneficial. With politicians and bureaucrats advocating on behalf of the mentally ill, the process of change would occur rapidly. Although, not leaders of the movement, sub-traditional leaders could also benefit society as families and groups begin to recognize the injustice on a larger scale.

\subsubsection{Mobilization}

A concern with regards to Mental Health Social Movement is the ability to mobilize, and, as discuss above,

147 University of Minnesota Human Rights Library, Introduction, Study Guide: The Rights of Indigenous People (2003) available at http:// www1.umn.edu/humanrts/edumat/studyguides/indigenous.html 148 Goodwin 42, citing to Tarrow 96-97 (1994).

149 Morris, Aldon, Leadership in Social Movements Aldon Morris and Suzanne Staggenborg, 1 (2002), available at http://www.sociology. northwestern.edu/people/faculty/documents/Morris-Leadership. pdf.

150 Id. at $2 . \mathrm{coo}$ 
in creating incentives to join the movement. Although Indigenous peoples had to overcome language, location, and other barriers to participate in the Indigenous movement, the many mentally ill would have even more difficulty advocating on their own behalf. Additionally, the Indigenous peoples often had the "material" incentive to mobilize, if they failed to act, often their land, resources, and way of life would be jeopardized. However, to advocate on behalf of the mentally ill would more similarly parallel the Disability Movement where many of those disabled received support from individuals whose selective incentives differed from direct material goals. This movement too has brought success. For example, the Americans with Disabilities Act ("ADA") was passed in the United States in the 1990s after multiple social movements of the 1960s and 1970s were effective in increasing awareness of unneeded institutionalization and the unequal treatment of these persons. ${ }^{151}$ Also, similar to the disabilities movement, a mental health movement could partially rely on persons unaffected by mental illness. Recently, the WHO has recognized that over the last 40 years the concept of "self-advocacy" has emerged, giving power and motivation to those who are affected by mental disorder and their family members. ${ }^{152}$ Additionally, within the 25 years the movement has grown to comprise not only severe illnesses, but also the mildly ill, and public mental health. ${ }^{153}$ This incorporation provides an incentive for mobilization as the general public could have more material gain from advocating than just "selective goods."

\subsubsection{Globalization}

According to Tarrow, "since the 1990s, an increasing number of contentious actors and actions have crossed national boundaries, united challenger from different countries, or targeted foreign and international targets." 154 For example, the transnationalization of a movement are the campaigns "mounted by coalitions of indigenous groups with support from NGOs abroad" in Northern Quebec, South America, and rural India "to stop the construction of major dams. .."

151 Cook, Thomas M., Disability Rights: A global grass-roots movement, The GazetTe (July 28, 2011), available at http://thegazette. com/2011/07/28/disability-rights-a-global-grass-roots-movement/

152 See Supra note 30, at 13.

153 Id.

154 See Supra note 110, at 235.
Similar to these movements, a mental health movement could feasibly transcend national borders. In the case of the dam construction, specific indigenous groups were represented by global NGOs who had the experience and ability to halt construction through litigation. In the case of mental illnesses, with the support of global mental health advocacy groups, the mental health advocacy groups could also effectively campaign through both global framing and transnational diffusion.155

\subsection{Outcomes of a mental health social movement}

As mentioned above, the current problems associated with human rights violations of the mentally ill include: (1) Lack of available care, (2) lack of cooperation to acquire the multidisciplinary action necessary to care for the mentally ill, (3) lack of education and (4) lack of effective mental health policy. Through a successful social movement, the four problems can feasibly be improved as "Advocacy has helped consumers make their voices heard and to show the real people behind the labels and diagnoses." ${ }^{156}$ The following section will briefly discuss how according to social movement theory, these problems could be improved to afford better protection to those currently suffering from mental illness.

\subsubsection{Available Care}

Globally, the available mental health care is appalling. "Only a small minority of people with mental disorders receive even the most basic treatment,"157 "only $51 \%$ of the world's population have access to treatment for severe mental disorders at the primary care level," and this treatment is "not necessarily effective or comprehensive." 158 As a movement advocates and increases persons understanding of mental illnesses, available care will increase due to demand, and also through promotion similar to physical healthcare advocates. This will likely be a slow process as mental health personnel are trained and societal perspectives are changed, but the outcome will greatly benefit society.

\footnotetext{
155 Id. See description.

156 See Supra note 30, at 9.

157 Id. 9.

158 Id. 10
} 


\subsubsection{Multidisciplinary Cooperation}

Lack of disciplinary cooperation causes a lacuna in care, but a multi-sectoral approach can also prevent deaths secondary to mental illness. Mental illness is a major risk factor for suicide within North America and Europe, and according to the WHO, there are currently one million suicides a year worldwide. ${ }^{159}$ The WHO also suggest that lack of suicide awareness and societal taboos have prevented countries from adequately addressing suicide. ${ }^{160}$ In reality the complexities of suicide are such that change in one sector of society alone is insufficient; suicide prevention necessitates a multidisciplinary approach from many professionals. ${ }^{161}$

Through a global movement, more institutions can be involved in mental illness care. This multi-disciplinary involvement will not only decrease suicide rates, but increase productivity as children with mental illnesses receive proper treatment. As children and adolescents receive adequate care, the likelihood of future criminal activity also decreases. Educators will be more aware of rights and privileges, the criminal justice system will be more efficient and housing could be fairly regulated.

\subsubsection{Education}

The general public should be educated in order to decrease stigma. ${ }^{162}$ Without an educated public, optimal legislation would be ineffective. It would resemble the desegregation laws which many states within the United States failed to enforce until further progression of the civil rights movement. As education changes perspectives and increases understanding of the pathophysiology of the illnesses, person will be more likely to abide by the laws enforced.

Educating mental health care providers could also lead to increased quality of care. As those performing the care are more educated, this creates the atmosphere to educate patients and families concerning illnesses.

159 Mental Health, Suicide Prevention (SUPRE), World Health Organization, available at http://www.who.int/mental_health/prevention/suicide/suicideprevent/en/ (last visited April 4, 2013).

160 Id. Challenges and Obstacles.

161 Id.

162 See Supra note 30, at 42. (See comment explanation of initiatives of developed countries to reduce stigma, increase financing, and laws to protect the rights of the mentally ill).

\subsubsection{Optimal Legis/ation}

One of the prospects of the activism would be to implement ideal mental health legislation. In order to implement effective norms the cooperation of both non-state and state actors is needed as both contribute to the development of "international norm-building."163

In 1996, the WHO Division of Mental Health and Prevention of Substance Abuse released ten basic principles of mental healthcare law after comparing the legislation of 45 different countries. ${ }^{164}$ These principles also draw upon the ideas recognized in the "Principles for the Protection of Persons with Mental Illness and the Improvement of Mental Health Care adopted by UN General Assembly Resolution 46/119 of 17 December 1991."'165 These principles include: (1) promotion of mental health and prevention of mental disorders (2) access to basic mental health care (3) mental health assessments in accordance with internationally accepted principles, (4) provision of the least restrictive type of mental health care, (5) self-determination, (6) right to be assisted in the exercise of self-determination, (7) availability of review procedure, (8) automatic periodical review mechanism , (9) qualified decision-maker, and (10) respect of the rule of law. ${ }^{166}$

These basic principles when applied would prevent numerous violations. For example, number four provides that the "least restrictive type of mental healthcare" be given. ${ }^{167}$ The components of this principle include providing community based-care when applicable and limiting restraints, chemical restraints, and isolation to the most extreme circumstances when necessary to prevent harm to the patient or others. ${ }^{168}$ Additionally, these mechanisms should have strict time limitations to prevent abuse, such as four hour restriction for physical restraints. ${ }^{169}$

163 See generally discussion, Levit, Reflections on the New Haven School (conveying the importance of "bottom-up" international lawmaking); Mertus, Kitchen Table (exploring how social movements wield influence over international norms); Mertus, Transnational Civil Society (arguing that non-state actors play a role in protecting human rights). As cited by Lillian Aponte Miranda, Indigenous Peoples As International Lawmakers, 32 U. Pa. J. Int'l L. 203, 210 (2010).

164 Mental Healthcare Law: Ten Basic Principles, Foreword, World Health Organization (1996), available at http://www.who. int/mental_health/media/en/75.pdf

165 Id.

166 Id. see Table of Contents

167 Id.

168 Id. at 4, Provision of the Least Restrictive Type of Mental Health Care: components.

169 Id. 
Principle number seven provides another example of a protective mechanism to prevent unnecessary restrictions of freedom, and greater patient autonomy. This principle, "the availability of review procedure," allows the individual to "be heard in person," and for the review to assure that a certain action is absolutely necessary to protect the individuals or others from harm. ${ }^{170}$

These basic standards, although "not a model act," provide a fundamental framework for change that can guide rule-makers to implement legislation which could significantly impact and reduce abuses of persons suffering from mental illness. ${ }^{171}$ However, to change policy, and implement the new policy, social awareness that a problem exist must too increase.

\section{Conclusion: The Need for a Current So- Cial Movement}

A social movement is essential in order to forestall the forthcoming mental health crisis. Through increa-

170 Id. at 7 Availability of Review Procedure.

171 Id. at Foreword sed awareness, and decreased stigma association, a social movement could be key to decreasing human rights violations of the mental ill.

The public needs to be engaged in a dialogue about the true nature of mental illnesses, their devastating individual, family and societal impacts, and the prospects of better treatment and rehabilitation alternatives. At the same time, stigmatizing attitudes need to be tackled frontally through campaigns and programmes aimed at professionals and the public at large. ${ }^{172}$

As activist initialize social movements, results could significantly assist millions of people suffering from stigma induced injustice. As a movement increases education, available care, multi-sectoral action, and legislation, it has the potential to increase not only quality of care, but availability of care. As quality of life improves for those suffering from mental illness, public productivity will also increase. Society's current taboo towards treatment disincentives those who need care to seek it, causing future problems, and without action, many receiving treatment will continue to suffer prolonged solitary confinement, unnecessary restraints, and other physical and verbal abuses, burdening the public, families, while worsening the conditions of those suffering.

172 See Supra note 18, at 19. 
Para publicar na Revista de Direito Internacional, acesse o endereço eletrônico www.rdi.uniceub.br ou www.brazilianjournal.org.

Observe as normas de publicação, para facilitar e agilizar o trabalho de edição. 